\title{
Penyuluhan Penyusunan Bahan Ajar Bahasa Indonesia yang Inovatif Bagi Guru-Guru SMP di Kabupaten Subang, Jawa Barat
}

\author{
Wikanengsih $^{1}$, Heri Isnaini ${ }^{2}$, dan Yesi Maylani Kartiwi ${ }^{3}$ \\ Program Studi Pendidikan Bahasa dan Sastra Indonesia, \\ IKIP Siliwangi, Cimahi, Jawa Barat ${ }^{1,2,3}$ \\ wikanengs@yahoo.com ${ }^{1}$, heriisnaini1985@gmail.com², Yesi.kartiwi@gmail.com
}

\begin{abstract}
This article describes the program of dedication in order to socialize the guidelines for the preparation of innovative teaching materials on Indonesian language for junior high school teachers in Subang district, West Java. The socialized teaching materials guide is an innovative teaching materials guide based on the utilization of technology and information based on the 4.0 industrial pattern of society. The method used in this socialization is the method of education and training so that the expected results become more maximal and can be a reference for teachers in drafting innovative teaching materials so that the teaching materials used In the learning process can improve the quality and ability of students in understanding the lesson. This counseling and socialization aims to deform the guidance of the preparation of innovative Indonesian teaching materials animation based and examples of text materials in the form of animation that is destined for junior high school teachers in Subang district, West Java So teachers are expected to have the ability and know the variety of teaching materials that can be conveyed to the students. In addition, animation-based text materials can contribute to the science of education, especially in Indonesian subjects.
\end{abstract}

Keywords: teaching materials, Indonesian text, innovative learning, junior high school curriculum

\begin{abstract}
Abstrak
Artikel ini mendeskripsikan program pengabdian dalam rangka sosialisasi panduan penyusunan bahan ajar inovatif pada mata pelajaran Bahasa Indonesia bagi guru-guru SMP di kabupaten Subang, Jawa Barat. Panduan bahan ajar yang disosialisasikan merupakan panduan bahan ajar yang inovatif berdasarkan pemanfaatan teknologi dan informasi berdasarkan pola masyarakat industri 4.0. Metode yang digunakan dalam sosialisasi ini adalah metode pendidikan dan pelatihan (diklat) sehingga hasil yang diharapkan menjadi lebih maksimal dan dapat menjadi rujukan bagi para guru dalam menyusun bahan ajar yang inovatif sehingga bahan ajar yang digunakan pada proses pembelajaran dapat meningkatkan kualitas dan kemampuan siswa dalam memahami pelajaran. Penyuluhan dan sosialisasi ini bertujuan untuk mendesimenasikan panduan penyusunan bahan ajar Bahasa Indonesia yang inovatif berbasis animasi dan contoh bahan ajar teks dalam bentuk animasi yang diperuntukkan bagi guru SMP di kabupaten Subang, Jawa Barat sehingga guru diharapkan memiliki kemampuan dan mengetahui variasi bahan ajar yang dapat disampaikan kepada para siswa. Selain itu, bahan ajar teks berbasis animasi dapat memberikan kontribusi terhadap ilmu pendidikan khususnya pada mata pelajaran Bahasa Indonesia.
\end{abstract}

Kata Kunci: bahan ajar, teks Bahasa Indonesia, pembelajaran inovatif, kurikulum SMP 


\section{Pendahuluan}

Dewasa ini, fakta yang ditemukan dalam dinamika dunia pendidikan masih memprihatinkan. Salah satunya yaitu kemajuan teknologi tidak berbanding lurus dengan kemajuan keterampilan guru. Masih ditemukan adanya perbedaan yang kontras antara keterampilan guru dengan keterampilan murid. Pengetahuan murid sudah sedemikian maju dalam masalah digital, sementara guru masih berkutat pada tradisi tekstual (Wartomo, 2016: 265).

Abad 21 ini guru sebenarnya dituntut untuk kreatif, kritis, dan produktif. Kreatif untuk menghasilkan karya-karya pendidikan seperti: pembuatan alat bantu belajar, analisis bahan ajar, penyusunan alat penilaian yang beragam dan sesuai kebutuhan zaman, dsb. Perkembangan ilmu pengetahuan dan teknologi saat ini memiliki peluang yang besar bagi para guru untuk bisa melakukan inovasi dan memilih strategi pembelajaran di kelas.

Oleh karena itu, peningkatan keterampilan bagi guru dalam memilih, menyusun, atau menggunakan perangkat pembelajaran untuk dapat mengimbangi perkembangan zaman perlu dilakukan. Guru perlu diberi pencerahan untuk selalu meningkatkan pengetahuan dan keterampilannya dalam menyiapkan perangkat pembelajaran. Salah satu yang dapat dilakukan oleh sivitas akademika perguruan tinggi dalam hal ini dosen IKIP Siliwangi yaitu melalui penyuluhan dan pendampingan kepada guru sebagai wujud pengabdian kepada masyarakat.

Bentuk pengabdian tersebut dapat dilakukan melalui penyuluhan kepada para guru dalam menyusun bahan ajar yang inovatif. Ketersediaan bahan ajar yang inovatif khususnya pada pelajaran Bahasa Indonesia saat ini sangat terbatas. Hal ini ini diketahui dari hasil observasi terhadap ketersediaan bahan ajar Bahasa Indonesia berbasis teks yang digunakan guru selama ini. Pada umumnya bahan ajar yang digunakan guru masih terbatas pada bentuk teks, berupa naskah yang ditulis pada buku.
Jarang sekali ditemukan bahan ajar Bahasa Indonesia dengan menggunakan teknologi informasi/digital/animasi.

Penggunaan bahan ajar dengan memanfaatkan teknologi informasi, salah satunya dalam bentuk animasi. Animasi diharapkan dapat menjadi faktor pendorong bagi semangat belajar siswa sehingga siswa tidak merasa bosan ketika mengikuti pelajaran bahasa Indonesia. Panduan penyusunan bahan ajar inovatif yang berbasis animasi beserta contohnya telah tersedia dari hasil penelitian kami. Sebagai wujud dari hilirisasi hasil peneitian agar bermanfaat bagi masyarakat (khususnya guru Bahasa Indonesia) maka kami berencana mendesimenasikan hasil penelitian tersebut melalui penyuluhan dan pendampingan kepada para guru Bahasa Indonesia di Kabupaten Subang, Jawa Barat. Desimenasi tersebut berupa penyuluhan tentang penyusunan bahan ajar inovatif (teks berbasis animasi) beserta contohnya yang merupakan hasil penelitian kami.

Berdasarkan latar belakang di atas, masalah yang dihadapi para guru Bahasa Indonesia adalah ketersediaan bahan ajar inovatif dan kemampuan guru dalam menyiapkan bahan ajar Bahasa Indonesia yang variatif. Prioritas masalah yang dapat diatasi melalui kegiatan pengabdian pada masyarakat yang berupa penyuluhan ini mencakup:

1) Kurangnya pengetahuan guru terhadap variasi/jenis-jenis bahan ajar yang diperlukan siswa;

2) Guru kurang terampil dalam menyusun bahan ajar yang bervariasi dan inovatif.

Pengabdian ini bertujuan untuk mendesimenasikan panduan penyusunan bahan ajar Bahasa Indonesia yang inovatif berbasis animasi dan contoh bahan ajar teks dalam bentuk animasi yang diperuntukkan bagi guru-guru SMP di Kabupaten Subang, Jawa Barat sehingga guru diharapkan memiliki kemampuan dan mengetahui variasi bahan ajar yang dapat disampaikan kepada para siswa. Selain itu, bahan ajar 
teks berbasis animasi dapat memberikan kontribusi terhadap ilmu pendidikan khususnya bidang pelajaran Bahasa Indonesia. Seperti yang dikemukakan oleh Akmaludin (2019) bahwa dalam pembelajaran, peran media pengajaran memiliki amanat penting dalam pengembangan pengetahuan di segala bidang ilmu pengetahuan dan teknologi.

\section{Pelaksanaan Dan Metode}

Program pengabdian ini dilaksanakan berdasarkan langkah-langkah yang telah disusun sebagai berikut.

1. Sosialisasi Program: sosialisasi program disampaikan kepada guruguru Bahasa Indonesia di kabupaten Subang, Jawa Barat.

2. Rencana Tindakan: Penjelasan tentang rincian aktivitas penyuluhan dan pendampingan kepada para guru Bahasa Indonesia tentang penyusunan bahan ajar inovatif berbasis animasi dan contoh bahan ajar teks dalam bentuk animasi dan bahan ajar inovatif lainnya.

3. Pelaksanaan penyuluhan.

4. Evaluasi kegiatan.

Metode pendekatan untuk menyelesaikan masalah dilakukan melalui transfer ilmu pengetahuan. Menurut Hidayat (2019) transfer ilmu adalah kegiatan seseorang dalam mengaplikasikan pengalaman dan pengetahuan yang dimilikinya untuk mempelajari atau memecahkan masalah (problem solving) dalam situasi baru. Proses transfer pengetahuan yang dilakukan melalui pendekatan transfer pengetahuan secara vertikal sebagai adopsi dari transfer teknologi.

Buku panduan tentang cara menyusun bahan ajar inovatif berupa animasi yang akan ditransfer kepada para guru merupakan hasil dari proses penelitian sebelumnya agar dapat dimanfaatkan/diterapkan secara nyata dalam dunia pendidikan. Hal itu dilakukan sebagai wujud hilirisasi hasil penelitian ke dunia pendidikan yang sesungguhnya sehingga hasil penelitian dapat aplikatif. Adapun pelaksanannya dilakukan melalui proses: menyimak, memahami, menyusun, dan menerapkan. Melalui proses-proses tersebut, proses inovasi dapat diadopsi secara berkesinambungan, serta target sasaran mempunyai kemampuan untuk menyusun dan menerapkan inovasi yang telah diterimanya. Supaya setiap proses berlangsung dengan baik, penyampaian inovasi kepada para guru ditempuh melalui tahapan penjelasan, diskusi, dan praktik.

Para guru merupakan amggota organisasi profesi yang aktif dan memerlukan pengetahuan dalam memilih dan menyusun bahan ajar dalam melaksanakan profesi keguruannya secara mandiri (Zainrrahman, 2013: 14). Dengan aktifnya guru maka pengetahuan dasar untuk menyusun bahan ajar sudah dimiliki namun masih belum mampu secara detail pada penyusunan bahan ajar yang inovatif. Jika bahan ajar disusun dengan bervariasi maka hasilnya akan maksimal dan tidak membosankan siswa. Hal ini akan berdampak pada kualitas hasil pembelajaran Bahasa Indonesia.

Evaluasi yang akan dilakukan terhadap pelaksanaan program kegiatan menggunakan model evaluasi CIPP yang dikemukakan oleh Klirkpatrick (Sudjana, 2006) dengan tahap sebagai berikut: 1) evaluating reaction. Yang dimaksud dengan evaluating reaction (reaksi evaluasi) yaitu mengevaluasi reaksi peserta pelatihan atau mengukur kepuasan peserta pelatihan melalui angket. Kepuasan peserta pelatihan dikaji dari beberapa aspek, yaitu materi yang diberikan, fasilitas yang tersedia, strategi penyampaian materi yang digunakan, media pembelajaran yang tersedia, serta jadwal kegiatan; 2) evaluating learning, mengukur tiga aspek yang diberikan pada saat pelatihan, yaitu sikap, pengetahuan, dan keterampilan; 3) evaluating behavior, yaitu penilaian tingkah laku yang difokuskan pada perubahan tingkah laku setelah peserta 
kembali ke tempat kerja dalam menerapkan pengetahuan yang telah diperoleh pada saat pelatihan; 4) evaluating result; ini difokuskan pada hasil akhir yang terjadi karena peserta telah mengikuti suatu program, yaitu peningkatan kualitas hasil belajar siswa karena penggunaan bahan ajar yang diterapkan guru. Hal ini merupakan evaluasi jangka panjang sehingga memungkinkan untuk keberlanjutan pelaksanaan program kegiatan pengabdian pada masyarakat ini.

\section{Hasil dan Pembahasan}

Menurut Umbara (2019) bahan ajar adalah segala bentuk bahan yang digunakan untuk membantu guru atau instruktur dalam melaksanakan proses pembelajaran di kelas. Pandangan ahli lainnya menyatakan bahwa bahan ajar adalah seperangkat materi yang disusun secara sistematis, baik tertulis maupun tidak tertulis, sehingga tercipta lingkungan atau suasana yang memungkinkan peserta didik untuk belajar.

Abidin (2016: 263) mengemukakan bahwa bahan ajar atau materi pembelajaran secara garis besar terdiri dari pengetahuan, keterampilan, dan sikap yang harus dipelajari siswa dalam rangka mencapai standar kompetensi yang ditentukan. Sejalan dengan Abidin, Prastowo (2015: 17) menyatakan bahwa bahan ajar merupakan segala bahan (baik informasi, alat maupun teks) yang disusun secara sistematis, yang menampilkan sosok utuh dari kompetensi yang akan dikuasai peserta didik dan digunakan dalam proses pembelajaran dengan tujuan perencanaan dan penelaahan implementasi pembelajaran, misalnya buku pelajaran, modul, handout, LKS, model atau maket, bahan ajar audio, bahan ajar interaktif, dan sebagainya.

Mahsun (2014: 1) mengemukakan pengertian teks, yaitu satuan bahasa yang digunakan sebagai ungkapan suatu kegiatan sosial baik secara lisan maupun tulis dengan struktur berpikir yang lengkap.
Bahan ajar dan teks dalam mata pelajaran Bahasa Indonesia merupakan dua hal yang tidak bias dipisahkan. Hal ini disebabkan karena basis pembelajaran Bahasa Indonesia adalah teks. Teks yang tidak dikemas dengan baik dan menarik akan mengakibatkan pembelajaran yang monoton dan tidak menarik. Dengan demikian, pola pembelajaran tidak akan berhasil dan cenderung membosankan.

Bahan ajar mata pelajaran bahasa Indonesia pada jenjang SMP terdiri atas beberapa jenis teks, di antaranya jenis teks anekdot, eksposisi, narasi, laporan hasil observasi, teks drama, teks puisi, dll.

Bahan ajar berupa teks tersebut pada umumnya disajikan dalam bentuk teks tertulis. Untuk memanfaatkan perkembangan teknologi dan informasi sesuai dengan tuntutan jaman di era mileneal ini maka berbagai fasilitas pembelajaran selayaknya memanfaatkan teknologi informasi tersebut.

Bahan ajar berupa teks sangat berpeluang disajikan dengan berbantuan teknologi informasi berupa animasi. Bentuk animasi tersebut diharapkan dapat meningkatkan kualitas pembelajaran dan kemampuan siswa dalam memahami berbagai jenis teks. Penyajian teks tersebut ke dalam bentuk animasi disesuaikan dengan teori jenis-jenis teks sehingga mudah dipahami siswa.

Bahan ajar berbasis animasi merupakan kombinasi dari dua atau lebih media (audio, teks, grafis, gambar, animasi, dan video) yang oleh penggunanya dimanipulasi atau diberi perlakuan untuk mengendalikan suatu perintah dan/atau perilaku alami dari suatu presentasi (Prastowo, 2015: 40) Bahan ajar berbasis animasi itu diharapkan dapat memberi motivasi kepada siswa sehingga pelajaran Bahasa Indonesia yang materinya berupa teks tidak membosankan siswa pada saat belajar. Selain itu, bahan ajar berbasis animasi dapat dijadikan media belajar bagi siswa.

Tahapan-tahapan penyuluhan dalam rangka pengabdian pembuatan bahan 
ajar bagi guru-guru Bahasa Indonesia di kabupaten Subang, Jawa Barat.

1. Pemaparan materi

Materi disampaikan berkenaan dengan cara-cara membuat bahan ajar yang inovatif menggunakan basis teknologi. Materi yang disampaikan berupa pemaparan pembuatan video animasi, penggunaan program camtasia, penggunaan program powerpoint, dan penggunaan teknik gambar.

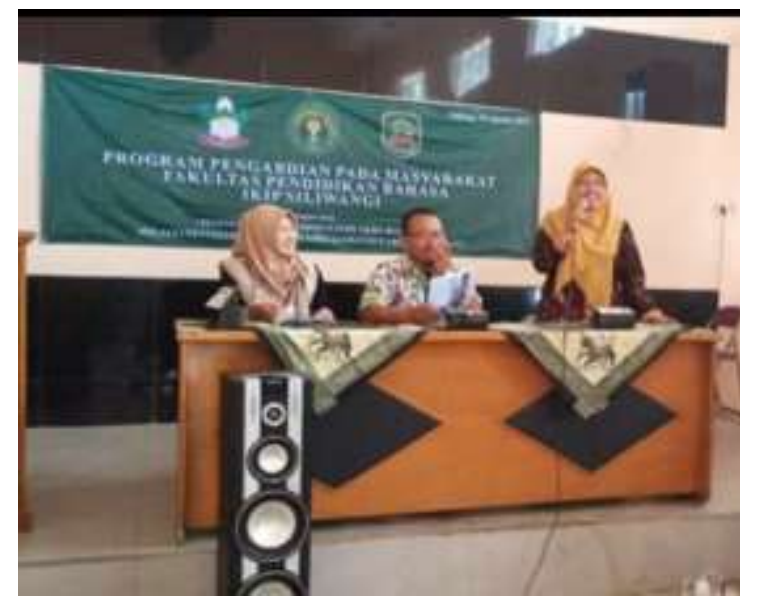

Gambar 1. Pemaparan materi penyuluhan pembuatan bahan ajar

Pembuatan bahan ajar dengan menggunakan animasi dijelaskan dengan menggunakan program after effect. Penggunaan program ini sangat membantu guru dalam menyampaikan materi di dalam kelas. Langkah-langkah telah disampaikan dan dipaparkan dalam kegiatan penyuluhan seperti berikut.

1. Buka After Effect.

2. klik Composition $>>$ New Composition $(\mathrm{Ctrl}+\mathrm{N})$.

3. Ada tampilan untuk mengatur nama, ukuran, warna background, duration timeline video, semuanya diatur sesuka hati.

4. Klik tombol icon teks yang bersimbol huruf "T" atau tekan (Ctrl+T).

5. Letakan cursor pada backround lalu klik kiri maka bisa membuat tulisan teks yang anda inginkan. Untuk mengatur jenis font, warna font, ukuran font ada tersedia di pinggir kanan dekat background.

6. Kita bisa animasikan dengan contoh keyframe opacity hal ini sangat penting karena terlihat smooth, anda bisa juga mengguanakan Scale (untuk memperbesar ataupun memperkecil teks tulisan), Position(Untuk menggeserkan letak object), untuk menganimasikan perhatikan bagian keyframenya karena ini dasar animasi untuk sebuah object.

7. Sesudah klik tombol Icon jam/Keyframe opacity, lalu pada timeline anda geser 1 detik mau kurang lebih terserah kita,(penjelasannya semakin besar timeline anda geser maka lebih lama object muncul, kalau menggesarnya anda sedikit maka lebih cepat obcject muncul), lalu rubah angka tertera yang sejajar opacity>dari $100 \%$ rubah menjadi $0 \%$.

8. Lalu test video pada RAM Preview terletak di atas kanan pojok, kita akan mengetahui animasi yang dihasilkan (Contonya saya menggunakan opacity animasi yang dihasilkan effect menghilang).

9. Kita akan munculkan kembali dengan mengeserkan timeline, terus klik lagi tombol keyframe paling kiri tombol yang diapit icon arah kanan kiri.

10. Tidak hanya bisa manual, Adobe After Effect menyediakan berbagai banyak fitur effect pada kolom disisi kanan, hal ini bisa memudahkan anda yang malas untuk membuat secara manual

11. Banyak sekali nama tipe effect yang tertera pada Folder, kita bisa memilih apa aja yang kita suka, (Contohnya saya pilih Transitions Dissolves) Klik untuk tipe pertama.

\section{Pada Folder Effect} Present $>$ Transitions 
Dissolves $>$ File pertama yang diklik lalu Drag pada object layer di timeline.

13. Kita bisa test lagi di RAM

Preview untuk bisa melihat jenis animasi yang pada di Folder tadi

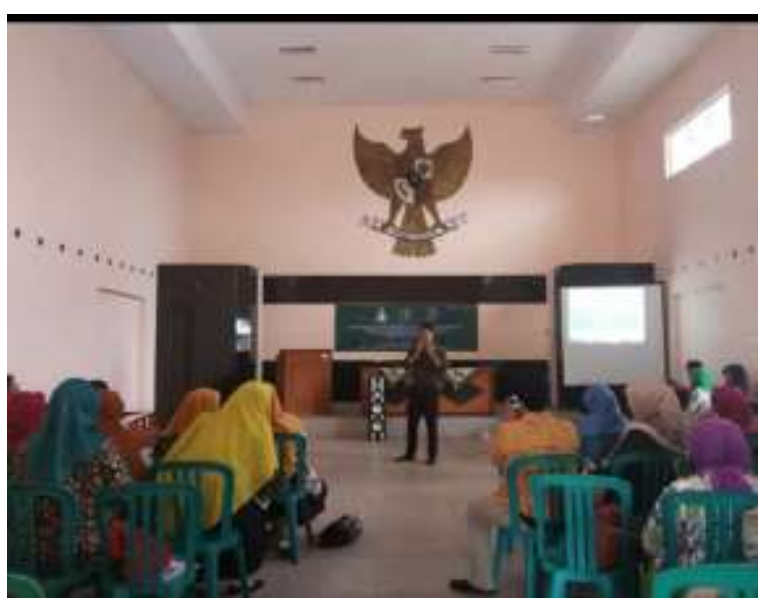

Gambar 2. Pemaparan materi penyuluhan pembuatan bahan ajar menggunakan after effect

\section{Latihan}

Latihan diberikan kepada guru-guru peserta penyuluhan dalam rangka tindak lanjut dari materi yang telah disampaikan. Latihanlatihan pembuatan bahan ajar ini dimulai dari bahan ajar yang paling sederhana sampai pada pembuatan bahan ajar yang lebih kompleks.

Tahapan-tahapan ini harus dilalui dan dilaksanakan dengan upaya dan tujuan agar penggunaan bahan ajar dalam pembelajaran tidak monoton dan tidak menimbulkan rasa bosan kepada siswa. Dalam latihan ini ditemukan banyak cara dari para guru yang pada akhirnya mengembangkan bahan ajar yang lebih kreatif dengan memanfaatkan bahan dan alat di sekitar sekolah sehingga dapat menekan biaya dan pembuatan bahan ajar tersebut.

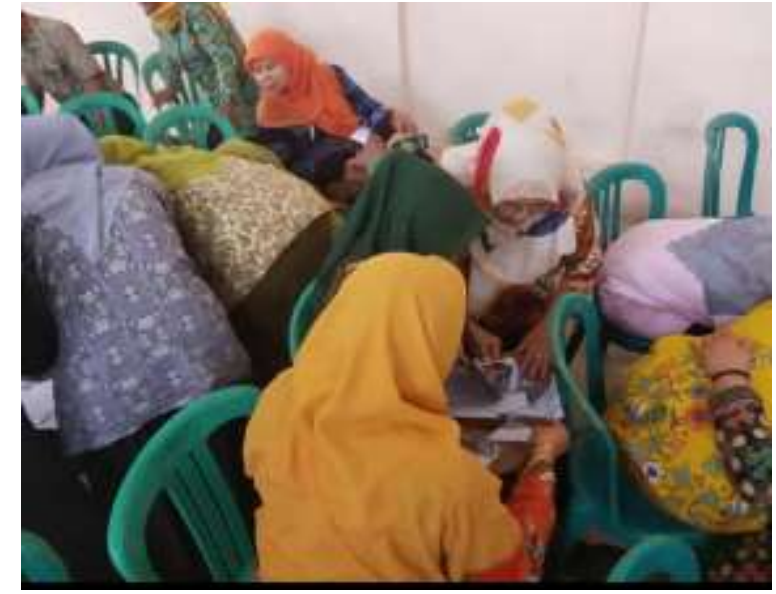

Gambar 3. Peserta penyuluhan sedang membuat bahan ajar dengan media kertas bergambar

Pembuatan bahan ajar dengan media gambar sebagai bahan pembelajaran untuk materi teks dalam mata pelajaran Bahasa Indonesia ini menjadi salah satu solusi pembuatan bahan ajar yang inovatif.

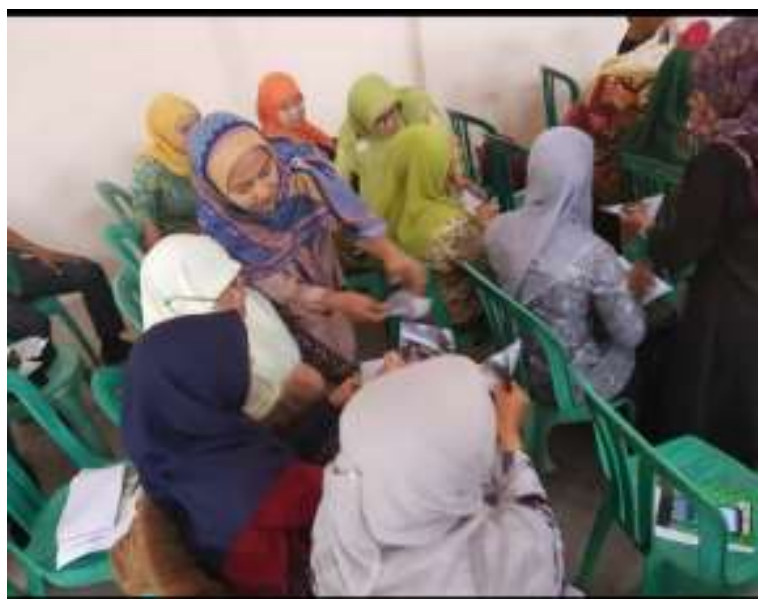

Gambar 4. Antusiasme peserta penyuluhan membuat bahan ajar dalam sesi latihan

Metode pendidikan dan pelatihan (diklat) dalam penyuluhan ini diharapkan menjadi lebih maksimal dan dapat menjadi rujukan bagi para guru dalam menyusun bahan ajar yang inovatif sehingga bahan ajar yang digunakan pada proses pembelajaran dapat meningkatkan kualitas dan kemampuan siswa dalam memahami pelajaran. Penyuluhan dan sosialisasi ini bertujuan untuk mendesimenasikan panduan penyusunan bahan ajar Bahasa 
Indonesia yang inovatif berbasis teknologi informasi dan contoh bahan ajar teks dalam bentuk animasi, gambar, program dan lain sebagainya yang diperuntukkan bagi guru SMP di kabupaten Subang, Jawa Barat sehingga guru diharapkan memiliki kemampuan dan mengetahui variasi bahan ajar yang dapat disampaikan kepada para siswa. Selain itu, bahan ajar teks berbasis animasi dapat memberikan kontribusi terhadap ilmu pendidikan khususnya pada mata pelajaran Bahasa Indonesia.

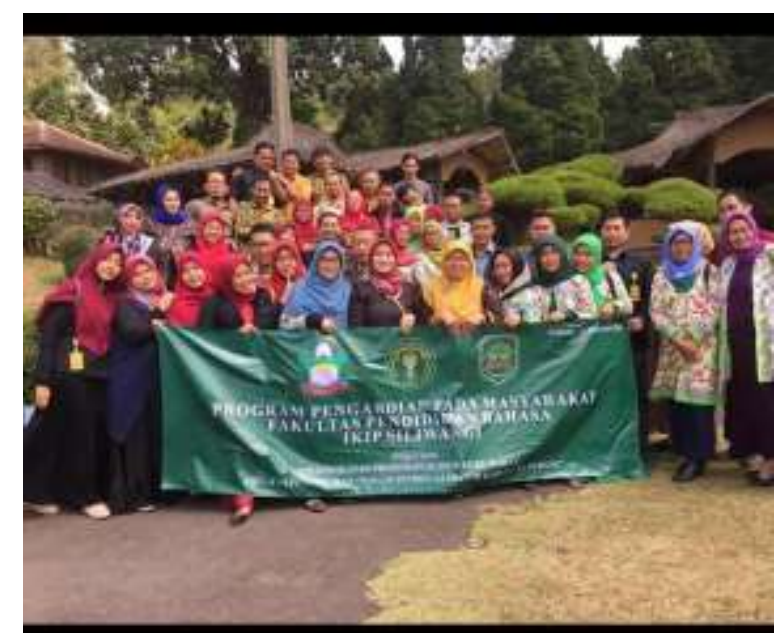

Gambar 5. Tim Program PPM Fakultas Pendidikan Bahasa, Prodi PBS. Indonesia

\section{Penutup}

\section{Simpulan}

Berdasarkan pembahasan di atas dapat disimpulkan bahwa pembuatan bahan ajar untuk mata pelajaran Bahasa Indonesia pada satuan Pendidikan tingkat SMP harus dibuat secara inovatif. Teks-teks yang diajarkan harus menarik dan tidak membosankan. Hasil penyuluhan yang dilakukan pada guruguru SMP di Kabupaten Subang, Jawa Barat telah menggambarkan bahwa guru-guru belum terbiasa menggunakan teknologi dalam rangka membuat bahan ajar yang menarik. Hal ini terbukti ada beberapa guru yang "gaptek" terhadap penggunaan teknologi. Ini menjadi catatan yang sangat berharga mengingat kondisi pembelajaran dewasa ini tidak terlepas dengan penggunaan teknologi yang sangat masif sehingga penyuluhan yang berkesinambungan menjadi kunci untuk membiasakan guruguru (terutama di daerah) untuk terbiasa menggunakan teknologi tersebut.

\section{Saran}

Keberlanjutan penyuluhan ini harus diupayakan terus menerus secara berkesinambungan. Ada beberapa faktor yang perlu diperhatikan. Di antaranya: upaya masif dari pemerintah daerah, (dinas Pendidikan) untuk menggalakan penggunaan teknologi kreatif dalam pembelajaran. Selain itu, upaya-upaya bertahap harus dilakukan dari Fakultas Ilmu Pendidikan dalam rangka pendampingan kepada guru-guru di daerah untuk membuat bahan ajar yang inovatif.

\section{Daftar Pustaka}

Astuti, Indah Yuni; Luayyi, Sri. (2019). Pelatihan Kewirausahaan Keterampilan Menjahit Bagi Masyarakat Desa Damarwulan Kecamatan Kepung Kabupaten Kediri. Cendekia: Jurnal Pengabdian Masyarakat, 1 No. 1, 19.

Abidin, Y. (2016). Desain Sistem Pembelajaran dalam Konteks Kurikulum. Bandung: Rafieka Aditama.

Akmaludin, Handayani, P., \& Septiana, L. (2019). Pelatihan Internet Pembuatan Blog bagi Guru-Guru HIMAPAUDI Kecamatan Kemayoran, Jakarta. $P P M$ Mathla`ul Anwar, 4 No. 2, 111-118.

Hidayat, M. T., Faiziyah, N., \& Listiawati, V. (2019). Workshop Penyusunan Program Unggulan OSN di MI Muhammadiyah Tegalampel, Klaten. PPM Universitas Mathla $u l$ Anwar, 4 No. 1, 1-10. 
Mahsun. (2014). Teks dalam Pembelajaran

Bahasa Indonesia. Jakarta:

Rajawali Press.

Nurgaha, D. A., \& Somatanaya, A. G. (2018). Worksho[ Perancangan dan Aplikasi Alat Peraga Mataematika Sekolah dasar. Jurnal Pengabdian Siliwangi, 4 No. 2, 23-30.

Permana, R. S. M., Puspitasari, L., \& Indriani, S. S. (2019). Pelatihan Post-Produksi (Audio-Visual Editing) Film Indie di Armidale English College Soreang, Bandung. PPM Universitas Mathla ul Anwar, 4, N0.1, 19-28.

Prastowo, A. (2015). Panduan Kreatif Membuat Bahan Ajar Inovatif. Yogyakarta: Diva Press.

Sudjana. (2006). Manajemen Program Pendidikan, untuk pendidikan Non Formal danPengembangan Sumber daya Manusia. Bandung: Falah Production.

Umbara, U., Rosyid, A., \& Setiawan, D. L. (2019). Pelatihan Pembuatan Media Pembelajaran Matematika Berbasis Flash Menggunakan Adobe Animate bagi Guru SMP di Kabupaten Kuningan. PPM Universitas Mathla`ul Anwar, 4, No. 1, 93-104.

Wartomo. (2016). Peran guru dalam pembelajaran era digital. Prosiding Temu Ilmiah Nasional Guru (Ting) VIII. Paper presented at the Temu Ilmiah Nasional, Jakarta.

Zainrrahman. (2013). Menulis: dari Teori hingga Praktik. Bandung: Alfabeta. 